
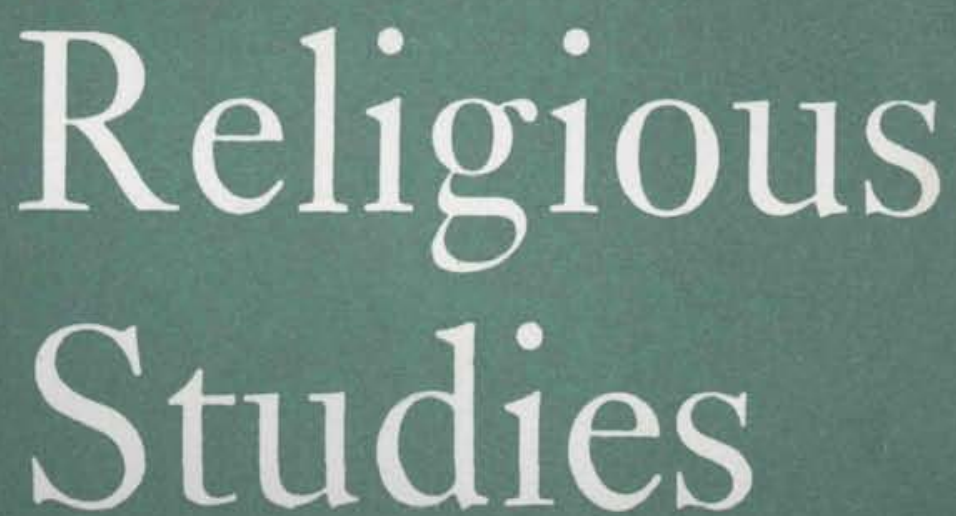

VOLUME 19 NUMBER 3 SEPTEMBER 1983 $0034-4125$

CAMBRIDGE UNIVERSITY PRESS 
Editorial Board

$\begin{array}{ll}\text { Professor C. F. Beckingham } & \text { Professor E. L. Mascall } \\ \text { Professor F. C. Copleston } & \text { Professor B. Mitchell } \\ \text { Mr K. D. D. Henderson } & \text { Professor H. P. OWen } \\ \text { Professor J. Hick } & \text { Professor G. Parrinder } \\ \text { Professor Trevor Ling } & \text { Professor Ninian SMart } \\ \text { Professor D. M. MackinNon } & \text { Professor G. C. Stead }\end{array}$

\section{Editorial Advisers}

Masao Abe, Professor of Religious Studies, Nara University of Education, Nara, Japan.

Fred Berthold, Professor of Religion, Dartmouth College.

Peter Bertocci, Professor of Philosophy, Boston University.

Carmen Blacker, Newnham College, Cambridge.

W. Cantwell Smith, Chairman, The Study of Religion, Harvard University.

Margaret Chatterjee, Professor of Philosophy, Delhi University.

Ian Crombie, Lecturer in Philosophy, Wadham College, Oxford.

J. N. Findlay, Professor of Philosophy, Boston University.

Allan D. Galloway, Professor of Divinity, Glasgow University.

D. W. Hamlyn, Professor of Philosophy, Logic and Ethics, Birkbeck College, London.

J. Harrison, Professor of Philosophy, University of Nottingham.
R. Hepburn, Professor of Philosophy, University of Edinburgh.

T. M. P. Mahadevan, Professor of Philosophy, University of Madras.

Kenneth W. Morgan, Professor of Religion, Colgate University.

T. R. V. Murti, Director of the Centre of Advanced Studies in Philosophy, Benares Hindu University, Varanasi 5, India.

D. A. Rees, Lecturer in Philosophy, Jesus College, Oxford.

Marcel Simon, Professor of the History of Religions, University of Strasbourg.

Robert Slater, Emeritus Professor of World Religions, Harvard University.

John Smith, Professor of Philosophy, Yale University.

G. Widengren, Professor of the History of Religions and Psychology of Religion, Uppsala University, Sweden.

Religious Studies is concerned with the main problems that present themselves in various fields of religious study. It provides a means of sustained discussion of the issues that have been sharpened by the course of recent philosophy and by the new findings of the historical and comparative study of religions. The psychology and sociology of religion, as they bear on major religious questions, come also within our scope. Space is reserved mainly for articles but there will also be extended book discussions, surveys of recent literature and book notes. It is hoped from time to time to publish replies to articles published in the journal and to provide in these and kindred ways a forum for debate of questions of importance in the study of religions today. Although authors will sometimes be encouraged to develop their views at some length the highest standards of precision and clarity are to be maintained.

(C) Cambridge University Press 1983

\section{Copyinc}

This journal is registered with the Copyright Clearance Center, 21 Congress St., Salem, Mass. org7o. Organizations in the U.S.A. who are also registered with C.C.C. may therefore copy material (beyond the limits permitted by sections 107 and 108 of U.S. copyright law) subject to payment to C.C.C. of the per-copy fee of \$o5.00. This consent does not extend to multiple copying for promotional or commercial purposes. Code $0034-4^{125} / 8_{3} / 3^{828-000 ~ I-\$ 05.00 . ~}$

ISI Tear Service, 3501 Market Street, Philadelphia, Pennsylvania 19104, U.S.A., is authorized to supply single copies of separate articles for private use only,

For all other use, permission should be sought from the Cambridge or New York offices of the Cambridge University Press.

\section{SUBSCRIPTIONS}

Orders, which must be accompanied by payment, may be sent to any bookseller or subscription agent, or direct to Cambridge University Press. The Edinburgh Building, Shaftesbury Road, Cambridge CB2 $2 R U$. Subscriptions in the U.S.A. and Canada should be sent to Cambridge University Press, 32 East 57 th Street, New York, N.Y. 10022 , U.S.A. Each volume of Religious Studies (ISSN o034-4125) is published in four parts, appearing in March, June, September and December. The subscription price, which includes postage, of Volume $19(1983)$ is $\AA_{3} 8.00$ net (U.S. $\$ 98.00$ in the U.S.A. and Canada) for institutions; f.20.00 (U.S. $\$ 49.00$ in U.S.A. and Canada) for individuals ordering direct from the Press and certifying that the journal is for their personal use. Single parts are available at $f_{12} .00$ (U.S. $\$ 30.50$ in U.S.A. and Canada), plus postage.

Claims for non-receipt of copies will not be entertained if they are made more than four months after publication.

Second class postage paid at New York, N.Y., and at additional mailing offices. POSTMASTER: send address changes in U.S.A. and Canada to Religious Studies, Cambridge University Press, 32 East 57 th Street, New York, N.Y. 10022. 